\title{
Pattern and Outcome of Typhoid Perforation in Benin City
}

\author{
OSIME O.C., and OSIFO O.D.,
}

\begin{abstract}
Over a 26-year period, there were only twenty four cases of perforated typhoid that were operated at the University of Benin Teaching Hospital. Four cases had incomplete data and were excluded from the study and only twenty cases were therefore included in the study. Of the twenty patients, there were 12 males and 8 females and the age range was between 11 and 45 years, with a mean of 25.65 years. The main complaints were fever, abdominal pain, vomiting, diarrhea or constipation. Most of the patients presented late to the hospital. Most of the patients had single perforations. Simple closure was the method of treatment in most of the patients. Wound infection was the major post operation complication. The average hospital stay was 16.3 days. We conclude that compared with other tertiary health institutions in Nigeria, the incidence of typhoid perforation is low at the University of Benin Teaching Hospital, Benin City, Nigeria and simple closure of perforations is efficient in managing typhoid perforations.
\end{abstract}

\section{INTRODUCTION}

Typhoid fever is caused by Salmonella typhi, and acquired by ingestion of food or water contaminated with excreta from a patient with typhoid or from a carrier. Human beings are the only reservoirs of Salmonella typhi. Incidence of typhoid fever has been reduced in many countries by control of the faecal-oral transmission of the

KEYWORDS: Typhoid Fever, Late presentation, Wound in infection

Department of Surgery, University of Benin Teaching Hospital, Pmb 1111, Benin City, Nigeria

Correspondence: Dr Osime O.c., Department Of Surgery, Ubth, Pmb 1111, Benin City, Nigeria.

Email:Clementosime@yahoo.com,Phone:08038780246 organisms. The disease continues to be a major health problem in developing countries. Gut perforation is the major complication with high morbidity and mortality. ${ }^{1-3}$ The some of the reasons for the associated complications are late presentation and delay in making a diagnosis. There is often delay in making a diagnosis because of some other acute abdominal conditions which constitute differential diagnosis of typhoid enteritis. ${ }^{4}$

Various patterns of presentation of typhoid fever and its associated complications have been reported from most centres in Africa. Communities without portable borne water are at a higher risk of the 
disease. Poor personal hygiene is also another key factor in determining the incidence of typhoid fever. While some communities record low incidence of typhoid enteritis, others have higher incidence. The incidence of perforated typhoid is closely associated with the incidence of typhoid enteritis. In communities with a high incidence of typhoid enteritis, there is associated high incidence of perforated typhoid., ${ }^{4,5}$

The purpose of this study is to present the pattern and outcome of typhoid perforation at the University of Benin Teaching Hospital over a 26 year period and to compare the findings with reports from other centres.

\section{MATERIALS AND METHODS}

The retrospective study which was carried out at the University of Benin Teaching Hospital (UBTH), covered between January 1980 and December 2005. UBTH is a tertiary health institution located in the centre of Benin City and caters for patients from Edo and other neighboring states in Nigeria. The case notes of patients that had surgery for perforated typhoid were retrieved and analysed for age, sex, symptoms on presentation, findings at operation and outcome of surgery. The main mode of management of patients with perforated typhoid at the University of Benin Teaching Hospital is laparotomy, simple closure of the perforation and peritoneal lavage. With regard to findings at operation, the number of perforations in the gut and the method of closure of the perforations were also analyzed. The average duration of onset of illness before presentation at the hospital was determined. The total number of days spent on admission was also analyzed. The morbidity and mortality were analyzed as well. Four case notes could not be obtained from the medical records and so were excluded from the study. The results are presented in simple tables.

Table I: Features and outcome of management of patients with typhoid perforation

\begin{tabular}{|c|c|c|c|l|c|l|l|c|}
\hline S/N & Sex & $\begin{array}{c}\text { Age } \\
\text { (yrs) }\end{array}$ & $\begin{array}{l}\text { Duration of } \\
\text { symptoms } \\
\text { before } \\
\text { presentation }\end{array}$ & $\begin{array}{l}\text { Chief symptoms } \\
\text { on presentation }\end{array}$ & $\begin{array}{c}\text { No of } \\
\text { perforations }\end{array}$ & $\begin{array}{l}\text { Type of } \\
\text { surgery }\end{array}$ & $\begin{array}{l}\text { Outcome of } \\
\text { surgery }\end{array}$ & $\begin{array}{c}\text { Duration of } \\
\text { hospital stay }\end{array}$ \\
\hline 1 & $\mathrm{M}$ & 11 & 5 days & $\begin{array}{l}\text { Fever, abdominal } \\
\text { pain, vomiting }\end{array}$ & 2 & $\begin{array}{l}\text { Sample } \\
\text { closure }\end{array}$ & $\begin{array}{l}\text { Had wound } \\
\text { infection did } \\
\text { well discharged }\end{array}$ & 19 days \\
\hline 2 & $\mathrm{~F}$ & 13 & 6 days & $\begin{array}{l}\text { Fever, abdominal } \\
\text { pain, diarrhea, } \\
\text { vomiting }\end{array}$ & 1 & $\begin{array}{l}\text { Sample } \\
\text { closure }\end{array}$ & $\begin{array}{l}\text { Had wound } \\
\text { infection did } \\
\text { well discharged }\end{array}$ & 26 days \\
\hline 3 & $\mathrm{~F}$ & 14 & 4 days & $\begin{array}{l}\text { Fever, abdominal } \\
\text { pain, bleeding, per } \\
\text { rectum, vomiting }\end{array}$ & 1 & $\begin{array}{l}\text { Sample } \\
\text { closure }\end{array}$ & $\begin{array}{l}\text { Did well and } \\
\text { discharged }\end{array}$ & 18 days \\
\hline 4 & $\mathrm{M}$ & 14 & 14 days & $\begin{array}{l}\text { Fever, abdominal } \\
\text { pain, vomiting }\end{array}$ & 3 & $\begin{array}{l}\text { Resection } \\
\text { and } \\
\text { ansatomosis }\end{array}$ & $\begin{array}{l}\text { Had wound } \\
\text { infection died }\end{array}$ & 19 days \\
\hline 5 & $\mathrm{M}$ & 16 & 12 days & $\begin{array}{l}\text { Abdominal pain, } \\
\text { vomiting }\end{array}$ & 1 & $\begin{array}{l}\text { Sample } \\
\text { closure }\end{array}$ & $\begin{array}{l}\text { Had wound } \text { infection did well } \\
\text { and discharged }\end{array}$ & 13 days \\
\hline 6 & $\mathrm{M}$ & 17 & 2 days & $\begin{array}{l}\text { Fever, abdominal } \\
\text { pain, constipation }\end{array}$ & 1 & $\begin{array}{l}\text { Sample } \\
\text { closure }\end{array}$ & $\begin{array}{l}\text { Did well and } \\
\text { discharged }\end{array}$ & 11 days \\
\hline 7 & $\mathrm{M}$ & 19 & 12 days & $\begin{array}{l}\text { Fever, abdominal } \\
\text { pain, vomiting, } \\
\text { constipation }\end{array}$ & 1 & $\begin{array}{l}\text { Sample } \\
\text { closure }\end{array}$ & $\begin{array}{l}\text { Did well and } \\
\text { discharged }\end{array}$ & 18 days \\
\hline
\end{tabular}




\begin{tabular}{|c|c|c|c|c|c|c|c|c|}
\hline 8 & M & 19 & 6 days & $\begin{array}{l}\text { Fever, abdominal } \\
\text { pain, diarrhea, } \\
\text { vomiting }\end{array}$ & 1 & $\begin{array}{l}\text { Sample } \\
\text { closure }\end{array}$ & Died & 5 days \\
\hline 9 & $\mathrm{~F}$ & 19 & 11 days & $\begin{array}{l}\text { Fever, abdominal } \\
\text { pain, vomiting, }\end{array}$ & 1 & $\begin{array}{l}\text { Sample } \\
\text { closure }\end{array}$ & $\begin{array}{l}\text { Did well and } \\
\text { discharged }\end{array}$ & 10 days \\
\hline 10 & $\mathrm{~F}$ & 22 & 12 days & $\begin{array}{l}\text { Abdominal pain, } \\
\text { vomiting }\end{array}$ & 1 & $\begin{array}{l}\text { Sample } \\
\text { closure }\end{array}$ & $\begin{array}{l}\text { Did well and } \\
\text { discharged }\end{array}$ & 14 days \\
\hline 11 & $\mathrm{~F}$ & 26 & 3 days & $\begin{array}{l}\text { Fever, abdominal } \\
\text { pain, diarrhea, }\end{array}$ & 1 & $\begin{array}{l}\text { Sample } \\
\text { closure }\end{array}$ & $\begin{array}{l}\text { Did well and } \\
\text { discharged }\end{array}$ & 11 days \\
\hline 12 & $\mathrm{M}$ & 26 & 20 days & $\begin{array}{l}\text { Fever, abdominal } \\
\text { pain, vomiting, }\end{array}$ & 1 & $\begin{array}{l}\text { Sample } \\
\text { closure }\end{array}$ & Died & 2 days \\
\hline 13 & $\mathrm{~F}$ & 27 & 5 days & $\begin{array}{l}\text { Fever, abdominal } \\
\text { pain, vomiting, }\end{array}$ & 1 & $\begin{array}{l}\text { Sample } \\
\text { closure }\end{array}$ & $\begin{array}{l}\text { Did well and } \\
\text { discharged }\end{array}$ & 10 days \\
\hline 14 & $\mathrm{M}$ & 30 & 7 days & $\begin{array}{l}\text { Abdominal pain, } \\
\text { vomiting }\end{array}$ & 1 & $\begin{array}{l}\text { Sample } \\
\text { closure }\end{array}$ & $\begin{array}{l}\text { Had wound } \\
\text { infection did well } \\
\text { and discharged }\end{array}$ & 32 days \\
\hline 15 & $M$ & 32 & 19 days & $\begin{array}{l}\text { Fever, abdominal } \\
\text { pain, vomiting, }\end{array}$ & 2 & $\begin{array}{l}\text { Sample } \\
\text { closure }\end{array}$ & $\begin{array}{l}\text { Had wound } \\
\text { infection, died }\end{array}$ & 15 days \\
\hline 16 & $\mathrm{~F}$ & 37 & 5 days & $\begin{array}{l}\text { Abdominal pain, } \\
\text { vomiting }\end{array}$ & 1 & $\begin{array}{l}\text { Sample } \\
\text { closure }\end{array}$ & $\begin{array}{l}\text { Did well and } \\
\text { discharged }\end{array}$ & 19 days \\
\hline 17 & M & 42 & 5 days & $\begin{array}{l}\text { Fever, abdominal } \\
\text { pain, vomiting, }\end{array}$ & 1 & $\begin{array}{l}\text { Sample } \\
\text { closure }\end{array}$ & $\begin{array}{l}\text { Had wound } \\
\text { infection did well } \\
\text { and discharged }\end{array}$ & 30 days \\
\hline 18 & $\mathrm{~F}$ & 42 & 11 days & $\begin{array}{l}\text { Fever, abdominal } \\
\text { pain, vomiting, } \\
\text { constipation }\end{array}$ & 1 & $\begin{array}{l}\text { Sample } \\
\text { closure }\end{array}$ & $\begin{array}{l}\text { Had wound } \\
\text { infection did well } \\
\text { and discharged }\end{array}$ & 20 days \\
\hline 19 & $\mathrm{M}$ & 42 & 2 days & $\begin{array}{l}\text { Abdominal pain, } \\
\text { vomiting }\end{array}$ & 2 & $\begin{array}{l}\text { Resection } \\
\text { and } \\
\text { ansatomosis }\end{array}$ & $\begin{array}{l}\text { Did well and } \\
\text { discharged }\end{array}$ & 15 days \\
\hline 20 & $\mathrm{M}$ & 45 & 14 days & $\begin{array}{l}\text { Fever, abdominal } \\
\text { pain, diarrhea, } \\
\text { vomiting }\end{array}$ & 1 & $\begin{array}{l}\text { Sample } \\
\text { closure }\end{array}$ & $\begin{array}{l}\text { Had wound } \\
\text { infection did well } \\
\text { and discharged }\end{array}$ & 19 days \\
\hline
\end{tabular}

\section{RESULTS}

There were 24 cases of perforated typhoid enteritis during the study period. Four cases whose files could not be retrieved were excluded from the study. Thus 20 patients studied; 12 males and eight females. The youngest patient was aged 11 years while the oldest was 45 years (with a mean age of 25.65 years). The chief symptoms on presentation were fever and abdominal pain. Eight patients (40\%) presented within the first 5 days of illness; the others presented later. Four patients had multiple perforations while the remaining patients had one perforation each. Of the four patients that had multiple perforations, two patients had resection and end to end anastomosis, while the remaining two patients and the 18 patients that had simple perforations had a simple repair of the perforations. There were four deaths and two of these were amongst those that presented late to the hospital. The remaining sixteen patients were treated and discharged.

\section{DISCUSSION}

Within the 26 years period of study there were only 24 cases of perforated typhoid (but only 20 patients were actually studied as 4 patients 
were excluded because of incomplete data). Compared with the findings from other similar tertiary hospitals, there is a very low incidence of typhoid perforation in Benin City. Meier et al ${ }^{4}$ reported 75 cases in a four year period. Similarly, Edino et $a l^{5}$ reported 47 cases over a 4 year period. Badejo et al in a 7-year period reported 201 cases of perforated typhoid. Other studies have similarly reported high incidence of typhoid perforation. Several reasons have been adduced for the regional variation in the incidence of typhoid perforation. While typhoid enteritis may not spare any social economic group, late presentation often complicated with typhoid perforation is more in lower socio-economic group. ${ }^{6}$

In the present study, the youngest patient was 11 years while the oldest was 45 years with a mean age of $25.65 \pm 5$ years. In the study by Adesunkanmi et $a l^{17}$ the male:female ratio was $4: 1$ with a mean age of 19.5 years and the study of Maier et $a l^{4}$ had mean age of 11.4 years. Edino et al reported a male:female ratio of 2.9:1 and a mean age of 18.9 years with the youngest being 4 years. Other studies have similarly reported male preponderance and a younger age group. ${ }^{7,8}$ The youngest patient in the present study was 11 years. Ugwu et $a l^{6}$ reported 101 cases of perforated typhoid over a 10 year period in Jos, with children under 16 years of age accounting for about $49 \%$. About $78 \%$ of the patients were in low social economic class.

Late presentation is a major problem in the developing countries. In the present study, the earliest the patients presented was 2 days after the onset of symptoms with a mean duration before presentation being 8.75 days. Other studies have similarly reported delays before presentation. Adesunkanmi et $a l^{7}$ found that late presentation was significantly associated with poor prognosis in patients with typhoid perforation. In the present study, of the four patients that died, three had presented late to hospital after the onset of symptoms. There is the great need therefore for adequate health education with a view to emphasizing the need for early presentation to hospital.

The chief symptoms on presentation were fever, vomiting, and abdominal pain. Few patients also had diaorrhea or constipation as presenting complaints. In the tropics where enteric fever is rather endemic, these symptoms should make the physician to suspect early that the patient may have typhoid enteritis and therefore commence early management to the morbidity and mortality associated with typhoid fever.

In the present study, $80 \%$ of the patients had single perforation. Of the $20 \%$ that had multiple perforations, one patient had 3 perforations, while the remaining three patients had 2 perforations each. In Akoh's ${ }^{11}$ study about $78 \%$ of the patients had single perforation. Similarly, other studies have shown that single perforation is more common than multiple perforation. ${ }^{7,89}$ In the present study, multiple perforation did not significantly affect the outcome of management as the number of deaths from single and multiple perforations were the same. However, in Adesunkanmi et al ${ }^{7}$ study, multiple perforation was significantly associated with poor outcome of management.

It is now universally accepted that treatment of typhoid perforation must be surgical. Adequate resuscitation, correction of electrolyte derangement, appropriate antibiotic therapy and surgery have proven to be essential for a successful outcome. ${ }^{7}$ Simple closure of the perforations was the method of 
management in the present study. Only the patient that had 3 perforations had a resection and end to end anastomosis. Other studies have similarly emphasized the effectiveness of simple closure of perforations especially when dealing with single perforations..$^{5-7}$ But for multiple perforation, most studies are in favour of resection and anastomosis. ${ }^{7}$

Wound infection was the main complication of management as $45 \%$ of the patients had wound infections. Other studies have similarly recognized wound infection as a major complication associated with surgery for typhoid perforation. ${ }^{6-8}$ In Adesunkanmi et $\mathrm{al}^{7}{ }^{7}$ study, while wound infection adversely affected the presence of residual intraabdominal abscess and faecal fistula, the incidence of residual intra-abdominal abscess was enhanced by the presence of faecal fistula. In the present study, there were no complications of faecal fistula or intraabdominal abscesses. Aggressive resuscitation, adequate antibiotic coverage and thorough lavage of the peritoneal cavity have been reported to help in minimizing the rate of wound infection associated with surgery for perforated typhoid.

The average hospital stay was 16.3 days with the longest staying patient staying for 32 days. Wound infection was the main reason for prolonged hospital stay. Inability to settle hospital bills was another reason for prolonged hospital stay. Other studies have also reported wound infection to be the main reason for prolonged hospital stay after surgery for perforated typhoid. ${ }^{13-16}$ The value of delayed wound closure was suggested by Adesunkanni et $a 1^{17}$

In conclusion, the incidence of typhoid perforation appears to be low in Benin City compared with other centres. The exact reason for this trend is not obvious, but seems that 'over diagnosis' and 'over treatment' of typhoid fever in Benin City may be contributory. However, this may not sufficiently explain the disparity. Other explanations could be differences in the patient loads in the different centres and also differences in the level of availability of portable water. But it will be worthwhile engaging in a more extensive study to evaluate these factors. Late presentation to the hospital was a major finding in our study and health education is recommended to encourage early presentation to hospital. Wound infections is a major complication following surgery for perforation typhoid, but adequate surgical skills and antibiotic coverage can minimize the incidence of wound infection and the associated morbidity and mortality following surgery for perforated typhoid.

\section{References}

1. Van Der Werf TS, Cameron ES. Typhoid perforation of the ileum: a review of 59 cases seen at Agogo hospital, Ghana between 1982 and 1987. Trop Geogr Med 1990; 42: 3306.

2. Otegbayo JA, Daramoyo OO, Onyegbuhulen HC, Balogun WF, Oguntoye OO. Retrospective analysis of typhoid fever in a tropical tertiary health facility. Trop Gastroventerol 2002;23:9 - 12.

3. Maurya SD, Gupta HC, Tiwari A, Sharman BD. Typhoid bowel perforation: A review of 264 cases. Int Surg 1984; 69: 1558.

4. Meier DE, Torpley JL. Typhoid intestinal perforation in Nigeria children. World J Surg 1998; 22:319-23. 
5. Edino ST, Mohammed AZ, Uba AT, Shasho AA, Arumah M, Ochicha O, et al. Typhoid enteric perforation in North Western Nigeria. Niger J Med 2004; 13: 345 - 9 .

6. Ugwu BT, Yiltok SJ, Kidmas AT, Opaluwa AS. Typhoid perforation in North Central Nigeria. West Afr J Med 2005; $24: 1$ - 6 .

7. Adesunkanmi ARK, Ajao OG. The prognostic factors in typhoid ileal perforation: a prospective study of 50 patients. J.R. Coll. Surg. Edinb. 1997; 42: 395 - 399.

8. Boomsma LJ. Clinical aspects of typhoid fever in two rural Nigerian hospitals: a prospective study. Trop Geog Med 1988; 40: 97 - 102.

9. Chamber CE. Perforation of ileum. Arch Surg 1972; 105: 550 - 2.

10. Eggleston FC, Santoshi B, Singh CM. Typhoid perforation of bowel. Ann Surg 1979; 190: 31 - 5 .

11. Agbakuru EA, Adesunkanmi AR, Fadiora SO, Olayenko OS, Aderonmu AO, Ogundoyin OO. A review of typhoid perforation in a rural African hospital. West Afr J Med 2003; 22: 22 - 5.
12. Welch TP, Martin NC. Surgical treatment of typhoid perforation. Lancet 1975; 1:1078 80.

13. Ameh EA, Dogo PM, Attah MM, Nmadu PT. Comparison of three operations for typhoid perforation. $\mathrm{Br}$ J Surg 1997; 84: 558601.

14. Badejo AO, Arigbagbu AO. Operative treatment of typhoid perforation with peritoneal irrigation: a comparative study of 210 cases in Ife (1972 1979) 1980; 21: 141 - 5 .

15. Santillana M. Surgical complications of typhoid fever enteric perforation. World J Surg 1991; 15: 170 - 5.

16. Ameh EA. Typhoid ileal perforation in children: a scourge in developing countries. Annal of Tropical Paediatrics: International child Health 1999; 19: 267 - 27.

17. Adesunkanmi ARK, Ajao OG. Typhoid ileal perforation: the value of delayed primary closure of abdominal wound. Afr J Med Medic Sci 1996, 25: $311-5$. 